\title{
BACTERIAL BIOFILM: A NOVEL ANTIGEN FOR ORAL VACCINATION OF FISH
}

\author{
Md. Abdullah-Al-Mamun ${ }^{*}$, Shamima Nasren ${ }^{1,2}$, Sanjay Singh Rathore ${ }^{3}$, \\ K. Rakesh ${ }^{3}$, Manjulesh Pai ${ }^{3}$ and Sathish Rama Poojary ${ }^{1}$ \\ Department of Fish Health Management, Faculty of Fisheries, \\ Sylhet Agricultural University, Sylhet-3100, Bangladesh
}

Bacterial biofilm is a structured community of bacterial cells enclosed in a self-produced polymeric matrix (= glycocalyx) and adherent to an inert or living surface, which constitutes a protected mode of growth that allows survival in harsh environment. Bacteria live in this type of communities for many reasons viz., protection from predators or other external dangers, access to resources, and genetic diversity. Free cell (FC) oral vaccines give poor and inconsistent immune response and protection in fish mainly due to their destruction by enzymes in stomach or foregut before reaching the immune responsive lymphoid organs. Biofilms (BF) are known for their resistant nature to antibiotics, antibodies and phagocytic cells due to a protective glycocalyx layer. Here, we discuss the pros and cons of biofilm oral vaccine which is believed to protect the antigens against gastric destruction and describe highly encouraging results (antibody titre and protection upon challenge) in herbivore carps, omnivore catfish (Clarias batrachus), tiger shrimp (Penaeus monodon) and carnivore fish (Channa striatus).

Aquaculture has been the fastest growing food-producing sector for years and the yield of aquaculture has overgrown the yield of wild capture fisheries. In 2014, fish harvested from aquaculture amounted to 73.8 million tonnes, consisting of 49.8 million tonnes of finfish, 16.1 million tonnes of molluscs, 6.9 million tonnes of crustaceans, and 7.3 million tonnes of other aquatic animals including frogs (FAO 2016). World aquaculture production (excluding aquatic plants) of fish accounted for 44.1 per cent of total production, 42.1 per cent in 2012 and 31.1 per cent in 2004 (FAO 2016). Intensification has come up as a boon to meet the increasing food demand. As a downside of this sector- wide intensification, increasing stocking densities give rise to high stress levels which in turn make fish more vulnerable to infections. Among the disease causing organisms, bacteria are one of the major pathogenic group.

*Author for correspondence:: <mamunff@gmail.com>. ${ }^{1}$ Department of Aquaculture, Laboratory of Aquatic Health Management, College of Fisheries, Karnataka Veterinary, Animal and Fisheries Sciences University, Mangalore 575002, Karnataka, India. ${ }^{2}$ Department of Fish Biology and Genetics, Faculty of Fisheries, Sylhet Agricultural University, Sylhet-3100, Bangladesh. ${ }^{3}$ Department of Aquaculture, College of Fisheries, Karnataka Veterinary, Animal and Fisheries Sciences University, Mangalore 575002, Karnataka, India.

(c) 2017 Zoological Society of Bangladesh DOI: http://dx.doi.org/10.3329/bjz.v45i2.35714 
To control bacterial and parasitic diseases, antibiotics and drugs were used indiscriminately. Antibiotic application had been an effective strategy in the beginning, but the residuals remaining in the rearing environment for long periods of time became a big challenge (Lakshmi et al. 2013). The indiscriminate use resulted in the emergence of antibiotic-resistant bacteria in aquaculture environments and increases the antibiotic resistance in fish pathogens (Verschuere et al. 2000). Therefore alternative means of disease management is imperative. In this present scenario, vaccination would be the best alternative to combat bacterial and viral disease for the sustainable aquaculture.

To date vaccines are available for most aquaculture fish species; most are targeting bacterial pathogens and only a few are raised against viruses. Depending on the age and size of the fish, commercial vaccines are administered either orally (by mixing with the feed), by immersion (dip or bath) or by injection through the intraperitoneal (i.p.) or intramuscular (i.m.) route (Embregts and Forlenza 2016). Vaccine by injection route although very effective in terms of immune response and long term protection but it has some side effects including tissue inflammation, adhesion and necrosis. On the other hand immersion vaccination required high production costs. Oral vaccines are an attractive alternative to reduce the stress on the fish during immunization (Gudding et al. 1999). Due to the ease, simplicity and practical applicability, oral vaccination became the choice of antigen delivery. However, attempts to orally vaccinate against different bacterial diseases have either yielded mild and shortlived or inadequate responses. One of the important factors for the inconsistency and poor response to oral vaccination is the digestive degradation of antigens in the foregut, before the vaccine reaches immune-responsive areas in the hind-gut and other lymphoid organs (Johnson and Amend 1983; Rombout et al. 1985).

To protect oral antigens from the gastric destruction several strategies were evaluated, such as encapsulated antigen microspheres, enteric coated vaccine and bioencapsulation of vaccine in live feed, these are complex, costly and impractical method (Siriyappagouder el al. 2014). In this respect biofilm vaccines would be the best alternative way for oral route of vaccination. Biofilm cell produce adhesive exopolymeric substance, which is called glycocalyx, offer protection to antigen from gastric destruction.

Over the 20 years, the vaccine research has been oriented towards safer and more effective vaccine preparation from a normal inactivated bacterial vaccine to the biofilm vaccine (Azad et al. 1997). Various researches conducted in the preparation of biofilm of Aeromonas hydrophila and Vibrio alginolyticus and its 
use as oral vaccine under the direct supervision of renowned Indian scientist and ICAR (Indian Council of Agriculture Research) Emeritus Professor Dr. K.M Shankar at the Laboratory of Aquatic Health Management, College of Fisheries, Mangalore have shown promising outcome in teleost fishes like catla, rohu, common carp (Azad et.al. 1997, 1999, 2000), catfishes like C. batrachus (Nayak et. al. 2004), tiger shrimp (P. monodon, Krupesh et. al. 2010) and C. striatus (Siriyappagouder et al. 2014).

The hypothesis was proposed and substantiated first by Azad et al. (1997, 1999). They isolated A. hydrophila, later developed to form biofilm on chitin flakes and successfully utilized it as oral vaccine in catla, rohu and common carp. Biofilm vaccinated carps had significantly higher antibody titer and protection than free cell (FC) vaccinated fishes. In subsequent attempt, Azad et al. (1999) standardized the dosage and duration for biofilm oral vaccination. A 20 day immunization with $10^{10} \mathrm{CFU} / \mathrm{g}$ fish/d proved to be ideal for oral vaccination.

Biofilm of A. hydrophila was successfully evaluated for oral vaccination of walking catfish (C. batrachus) (Nayak et al. 2004 ). Fish were fed with biofilm (BF) or free cells (FC) of A. hydrophila for 20 days, and monitored for serum antibody production up to 60 days post-vaccination. They found significantly higher antibody titer and relative per cent survival (RPS) in catfish fed with BF vaccine compared to that with $\mathrm{FC}$ following challenge test. Immune response in juvenile tiger shrimp, $P$. monodon fed with biofilm (BF) and free cells (FC) of $V$. alginolyticus was studied by Krupesh et al. 2010. Among the different doses of $\mathrm{BF}$ of $V$. alginolyticus tested, $10^{9} \mathrm{cfu} / \mathrm{g}$ shrimp/day for two weeks could elicit higher immune response. $\mathrm{BF}$ fed shrimp were more resistant to injection challenge with $V$. alginolyticus and white spot syndrome virus (WSSV) with significantly higher RPS compared to that with FC fed and control shrimp. Another study by Siriyappagouder et al. 2014, with C. striatus, a carnivorous fish model, fed with biofilm (BF) and free cell (FC) of $A$. hydrophila with the same dose and duration of Nayak et al. 2004. They observed BF vaccinated fish upon challenge with $A$. hydrophila at $10^{9} \mathrm{cfu} / \mathrm{ml}$ had significantly higher relative per cent survival (88) than that of FC (29.6).

Biofilm cells proved to be effective as oral vaccination of fin and shellfishes. Production of biofilm vaccines and its efficacy has been proven in institutional research experiments, now it is high time to produce on a large commercial scale to address the infectious diseases. It can be considered as simple, cheap and ideal oral vaccination technique for bulk administration. 


\section{LITERATURE CITED}

AZAD I.S., SHANKAR K.M., MOHAN C.V. and KALITA B. 2000. Uptake and processing of biofilm and free-cell vaccines of Aeromonas hydrophila in Indian major carps and common carp following oral vaccination- antigen localization by a monoclonal antibody. Dis. of Aquat. Org. 43: 103-108.

AZAD, I. S., SHANKAR, K.M. and MOHAN, C.V. 1997. Evaluation of an Aeromonas hydrophila biofilm oral vaccination of carps. IM; Diseases in Asian aquaculture III (T.W. Flegal and I.H.Macrae, eds.), Fish health section, AFS, Manila, pp.181-186.

AZAD, I.S., SHANKAR, K.M. and MOHAN, C.V. 1999. Biofilm vaccine of Aeromonas hydrophila standardization of dose and duration for oral vaccination of carps. Fish and shellfish Immunol., 9: $519-528$.

EMBREGTS, C.W.E. and FORLENZA, M. 2016. Oral vaccination of fish: Lessons from humans and veterinary species. Dev. and Comp. Immunol. 64: 118-137.

FAO 2014. The State of World Fisheries and Aquaculture. Food and Agriculture Organization of the United Nations, Rome, ISBN 92-5-105177-1.

GUDDING, R., LILlEHAUG, A. and EVENSEN, O. 1999. Recent developments in fish vaccinology. Vet. Immunol. Immunopathol. 72: 203-212.

JOHNSON, K. A. and AMEND, D.F. 1983. Efficacy of Vibrio anguillarum and Yersinia ruckeri bacterin applied by oral and anal intubation of salmonids. J. Fish Dis. 6: 473-476.

KRUPESHA, S. R.S., SHANKAR, K.M., SATHYANARAYANA, M.L., SAHOO, A.K., PATIL, R., NARAYAN, S.H.D. and RAO, S. 2010. Evaluation of immune response and resistance to diseases in tiger shrimp, Penaeus monodon fed with biofilm of Vibrio alginolyticus. Fish and shellfish Immunol. 29: 724-732.

LAKSHMI, B., VISWANATH, B. and SAI GOPAL D.V.R. 2013. Probiotics as antiviral agents in shrimp aquaculture. J. Pathog. Article ID 424123, p.13.

NAYAK, D.K., ASHA, A., SHANKAR, K.M. and MOHAN, C.V. 2004. Evaluation of biofilm of Aeromonas hydrophila for oral vaccination of Clarias batrachus - A carnivore model. Fish and Shellfish Immunol. 16(5): 613-619.

ROMBOUT, J.W.H.M., LAMERS, C.H.J., HELFRICH, M.H., DEKKER, A. and TAVERNE-THIELE, A. J. 1985. Uptake and transport of intact macromolecules in the intestinal epithelium of carp (Cyprinus carpio L.) and the possible immunological implications. Cell Tiss Res. 239: 519-530.

SIRIYAPPAGOUDER, P., SHANKAR, K.M., NAVEEN KUMAR, B.T., PATIL, R. and BYADGI, O.V. 2014. Evaluation of biofilm of Aeromonas hydrophila for oral vaccination of Channa striatus. Fish and Shellfish Immunol. 41(2): 581-585.

VERSCHUERE, L., ROMBAUT, G., SORGELOOS, P. and VERSTRAETE, W. 2000. Probiotic bacteria as biological control agents in aquaculture. Microbiol. Molecul. Biol. Rev. 64(4): 655-671. 